\title{
The molecular components of phospho- and glycolipid metabolism in $p$ lant cell membranes under the phosphorus deficiency
}

\author{
N. B. Svietlova \\ Educational and Scientific Center «Institute of Biology», \\ National Taras Shevchenko University of Kyiv \\ 64/13, Volodymyrska Str., Kyiv, Ukraine, 01601 \\ svyetlova@rambler.ru
}

\begin{abstract}
One of the aspects of molecular regulation of phosphorus metabolism in plants, the lipid components of membrane structures, has been reviewed. The refocusing of phospho- and glycolipid metabolism is an indicator of phosphorus accessibility in plants. The compensatory mechanisms of substitution of phospholipids with non-phosphorus containing glycolipids in membranes, allow plants to adapt to the phosphate $\left(P_{i}\right)$ starvation. Phospholipids are the reserve pool of cellular phosphorus at reutilization of ions in the donor-acceptor system of plants. The mechanisms of transcriptional regulation of genes involved in the synthesis of phospholipids and glycolipids under $P_{i}$ deficit have been analyzed.
\end{abstract}

Keywords: phosphate starvation, monogalactosyl diacylglycerol, digalactosyl diacylglycerol, sulfoquinovosyl diacylglycerol, phosphatidyl glycerol, MGD, DGD, SQD, PLDz, NCP genes.

The maintenance of homeostasis and the metabolism control are defined by the cellular signalling in the donor-acceptor system of plants. While a plant organism responds to the change in the environmental conditions, the key role in the control of cell signalling is attributed to phosphorus. Being an essential structural and functional component of many key macromolecules, nucleic acids, highly energetic structures (AMP, ADP, ATP), membrane phospholipids, phosphorus participates in many metabolic processes in plants: energy transfer, carbohydrate assimilation, breathing, lipid biosynthesis and regulation of enzyme activity [1-4].

In the process of evolution the plants developed different adaptation mechanisms in response to phosphorus $\left(\mathrm{P}_{\mathrm{i}}\right)$ deficiency. The decrease in the concentration of phosphorus ions in the plant cell to the critical level is a signal to launch reciprocal stress, causing an activation of the alternative metabolic

(c) Institute of Molecular Biology and Genetics, NAS of Ukraine, 2012 pathways, directed towards the mobilization and decreased use of phosphorus in plants [3,4]. The maintenance of constant phosphorus concentrations in the organism is achieved via the input of $\mathrm{P}_{\mathrm{i}}$ from outside, storing, re-mobilization and re-utilization of phosphorus in the donor-acceptor system of plants in accordance to the priorities in the distribution of assimilates during their growth and development $[4,5]$.

One of the regulatory mechanisms of maintaining optimal concentrations of phosphorus ions in the plant cell is related to the modification of membranes structure and the change in the rate and direction of metabolism of lipid components in all subcellular compartments.

The control on lipids metabolism in the process of organelle biogenesis in plants is achieved via coordinated interaction between mitochondria, nucleus and chloroplasts. Photosynthetic membranes of organisms, from cianobacteria to spermatophytes, contain two neutral galactolipids - mono- and digalactosyl diacylglycerol (MGDG and DGDG), and 
two anion lipids - phosphate-containing phosphatidyl glycerol (PG) and sulfur-containing sulfoquinovosyl diacylglycerol (SQDG). The major neutral lipids of plasmatic membranes are galactolipid DGDG and phospholipid phosphatidyl choline (PC). Besides PC, among phospholipids, present in plasmatic membranes, there are also phosphatidyl etanolamin (PE), phosphatidylinositol (PI) and in insignificant quantities - PG [6-8].

SQDG in plant cells is localized only in plastid membranes while PG is present in plastid membranes as well as and others though in insignificant quantities. PG is the only phospholipid, contained in thylakoids and in the internal membrane of chloroplasts. A third of organic phosphates in plants, in Arabidopsis thaliana in particular, belong to phospholipids [9].

The developed system of membrane structures and the diversity of membrane lipid composition allow the cells to function with minimal phosphorus consumption which is crucial for plants since the deficiency of this chemical element is often restrictive for their growth and development $[3,10]$.

The transcriptional control of metabolism of phospho- and glycolipids under $P_{i}$ deficiency. The genes, controlling synthesis, degradation and transformation of lipid components, phospho- and glycolipids, in particular, are considered as an essential constituent of the plant regulatory system, involved in the response to $P_{i}$ deficiency. The quantitative changes in the phospho- and glycolipids are an important index of $\mathrm{P}_{\mathrm{i}}$ deficiency in plants (Table).

To date there are three known genes, participating in MGDG biosynthesis: $M G D 1, M G D 2$ and $M G D 3$, composing the multigene family of MGDG synthases (EC 2.4.1.46). There are two types of MGDG-synthases: type A (MGD1) and type B (MGD2 and MGD3) [11-14].

MGDG-synthase, type A, is expressed in photosynthetic tissues during the plant growth and development in the presence of $\mathrm{P}_{\mathrm{i}}$. It is responsible for the mass synthesis of MGDG, required for the biogenesis of internal membranes of chloroplasts and expansion of the network of thylakoids.

MGDG synthase, type B, does not participate in the galactolipid synthesis under conditions of $P_{i}$ saturation and is expressed only at its deficiency in plants.
MGDG-synthase, synthesized with the participation of $M G D$ gene type $\mathrm{B}$, is mainly localized in non-photosynthetic tissues: in inflorescences (MGD2) and roots $(M G D 3)$. The expression of $M G D$ gene of this type is essential for the launch of alternative pathway of biosynthesis of galactolipids at $\mathrm{P}_{\mathrm{i}}$ deficiency.

The functional distribution between the internal $(M G D 1)$ and external membranes $(M G D 2 / 3)$ of chloroplasts, corresponding to the degree of phosphorus provision for plants, is mainly controlled by the level of phytohormones and light intensity. In particular, the expression of MGD1 gene is regulated by light intensity and content of cytokinins. The $\mathrm{P}_{\mathrm{i}}$-dependent expression of $M G D 2 / 3$ is inhibited by cytokinins and induced by auxin-dependent signalling pathways $[15,16]$.

The DGDG biosynthesis is regulated by the transcription of genes of DGDG-synthases (EC 2.4.1.241): $D G D 1$ and $D G D 2$ [17]. The study of plants dgd1/phol demonstrated that the mutation PHO1, blocking the input of $\mathrm{P}_{\mathrm{i}}$ into the xylem, in combination with the mutation $D G D 1$ leads to the restoration of DGDG biosynthesis [18]. Since $D G D 1$ mutation is characterized by the presence of stop-codon in the site of coding $D G D 1$, which results in the $90 \%$ decrease in DGDG biosynthesis [12], the restoration of its content testifies to the presence of $D G D 1$-independent pathway of galactolipid biosynthesis. The creation of genetically modified A. thaliana plants $d g d 1$ and $d g d 1 /$ phol resulted in the identification of the second gene, responsible for the DGDG synthesis ? DGD2, activated at $\mathrm{P}_{\mathrm{i}}$ deficiency [17].

The construction of a model system in vitro using MGDG and uridine-5-diphosphate (UDP)-galactose as a substrate promoted the study on DGDG synthase activity. It was determined that UDP-galactose (EC 2.4.1.46) and not MGDG is a galactose donor for DGDG, the synthesis of which is conditioned by the level of $D G D 2$ expression. The creation of this model system confirmed the dependence of DGDG synthesis on the availability of UDP-galactose in higher plants [19].

The presence of an additional pathway of galactolipid synthesis, independent from the transcription of DGD1 and DGD2 genes, was discovered in modified plants $d g d 1 / d g d 2$. Since plants 
Transcriptional regulation of A. thaliana genes, participating in the synthesis and transformations of glyco-and phospholipids at $P_{i}$ deficiency

\begin{tabular}{|c|c|c|c|}
\hline $\begin{array}{c}\text { Mutant gene } \\
\text { (locus No.) }\end{array}$ & Specificities of functioning & $\begin{array}{l}\text { Transgene line of } \\
\text { genetic models of } \\
\text { plants }\end{array}$ & Characteristics \\
\hline $\begin{array}{c}S Q D 2 \\
(\mathrm{At5g} 01220)\end{array}$ & $\begin{array}{l}\text { Biosynthesis of sulfolipid; localized on the inter- } \\
\text { nal membrane of chloroplasts; encoding UDP- } \\
\text { sulfoquinovoso-DAG-sulfoquinovosyl transferase } \\
\text { (EC 2.4.1.8); transfer of sulfoquinovosyl groups }\end{array}$ & $\begin{array}{c}s q d 2 \\
(\mathrm{At} 5 \mathrm{~g} 01220.1)\end{array}$ & $\begin{array}{l}\text { Reduction of SQDG synthesis; inhibition of } \\
\text { growth at } P_{i} \text { deficiency }[28,29]\end{array}$ \\
\hline
\end{tabular}

$\operatorname{mgd} 1$ cipation in MGDG synthesis in $\mathrm{P}_{\mathrm{i}}$ presence; localization on the external membrane of chloroplasts; encoding MGDG synthase, type B (UDPgalactoso-1,2-DAG-galactosyl transferase); induction in non-photosynthetic tissues

MGD3 Biosynthesis of MGDG in $\mathrm{P}_{\mathrm{i}}$ absence; no promo(At2g11810) tion of synthesis of galactolipids in $\mathrm{P}_{i}$ presence; localization on the external membrane of chloroplasts; participation in metabolic processes of fatty acids; encoding MGDG-synthase, type B (UDP-galactose-1,2-DAG-galactosyl transferase)

$D G D 1$

(At3g11670)

Biosynthesis of DGDG; localization on the external membrane of chloroplasts, in mitochondria; provision of the ultimate composition of galactolipids in photosynthetic membranes; stabilization of subunits PsaD, PsaE of the main PSI complex; encoding synthase DGDG (UDP-galactosoMGDG-galactosyl transferase); catalysis of galactose transfer from UDP galactose to the acceptor molecule

DGD2 Biosynthesis of DGDG; localization on the exter(At4g00550) nal membrane of chloroplasts; encoding DGDG synthase (UDP-galactoso- MGDG- galactosyl transferase); catalysis of galactose transfer from UDP-galactose to the acceptor molecule

PLDz1 Degradation of phospholipids and synthesis of (At3g16785) galactolipids in roots; encoding subfamily of proteins PXPH-PLD of phospholipase D; regulation of root architecture at $\mathrm{P}_{\mathrm{i}}$ deficiency

$P L D z 2 \quad$ Production of phosphatidic acid at $\mathrm{P}_{\mathrm{i}}$ deficiency; (At3g05630) induction in roots and rosettes at $\mathrm{P}_{\mathrm{i}}$ deficiency; encoding subfamily of PXPH-PLD proteins of phospholipase D; promotion of hydrolysis of PC and $\mathrm{PE}$ with the formation of $\mathrm{DAG}$; no regulation of root fibril architecture at $\mathrm{P}_{\mathrm{i}}$ deficiency
(At4g31780.1;

At4g31780.2)

$\operatorname{mgd2}$

(At5g20410.1)

Reduction of MGDG synthesis in leaves to $75 \%$; presence of yellow and green leaves due to disorder of biogenesis of chloroplasts $[11,15,39,50]$

Reduction of DGDG content and change in the composition of fatty acids of galactolipids in leaves and roots at $\mathrm{P}_{\mathrm{i}}$ deficiency; no biochemical and phenotypic changes are revealed at optimal supply of $\mathrm{P}_{\mathrm{i}}[11,15,39,50]$

$m g d 3$

(At2g11810.1;

At2g11810.2)

Reduction of DGDG content and change in the composition of fatty acids of galactolipids in leaves and roots at $\mathrm{P}_{\mathrm{i}}$ deficiency; no biochemical and phenotypic changes at optimal supply of $\mathrm{P}_{\mathrm{i}}$ $[11,15,39,50]$

$d g d 1$

(At3g11670.1; At3g11670.2)

Reduction of DGDG synthesis to $90 \%$; diminution of growth, defects in seed color, pale leaves, reduction of photosynthetic potential and change in thylakoid structure (formation of "convoluted" thylakoids) $[12,39,51]$

$d g d 2$

(At4g00550.1)

Absence of phenotypic specificity under normal conditions of cultivation $[12,17,39]$

pldz 1

(At3g16785.1)

Inhibition of growth of the main root and elongation of side roots at $\mathrm{P}_{\mathrm{i}}$ deficiency [34-36]

pld $z 2$

(At3g05630.1)

Disorder of hydrolysis of phospholipids, reduced capability of accumulating galactolipids; changes in root morphology at $\mathrm{P}_{\mathrm{i}}$ deficiency [34-36] 


\begin{tabular}{|c|c|c|c|}
\hline $\begin{array}{l}\text { Mutant gene } \\
\text { (locus No.) }\end{array}$ & Specificities of functioning & $\begin{array}{l}\text { Transgene line of } \\
\text { genetic models of } \\
\text { plants }\end{array}$ & Characteristics \\
\hline $\begin{array}{c}\text { NPC4 } \\
(\mathrm{At} 3 \mathrm{~g} 03530)\end{array}$ & $\begin{array}{l}\text { Production of phosphatidic acid at } \mathrm{P}_{\mathrm{i}} \text { deficiency; } \\
\text { induction in roots and rosettes at } \mathrm{P}_{\mathrm{i}} \text { deficiency; } \\
\text { encoding subfamily of PXPH-PLD proteins of }\end{array}$ & $\begin{array}{c}n p c 4 \\
(\text { At3g03530.1) }\end{array}$ & $\begin{array}{l}\text { Disorder of hydrolysis of phospholipids, reduced } \\
\text { capability of accumulating galactolipids; changes } \\
\text { in root morphology at } \mathrm{P}_{\mathrm{i}} \text { deficiency [34-36] }\end{array}$ \\
\hline $\begin{array}{l}\text { NPC5 } \\
(\text { At3g03540) }\end{array}$ & $\begin{array}{l}\text { Деградация фосфолипидов и синтез галакто- } \\
\text { липидов в листьях в условиях дефицита } \mathrm{P}_{i} \text {; ло- } \\
\text { кализован в цитозоле; кодирует неспецифи- } \\
\text { ческую фосфолипазу С }\end{array}$ & $\begin{array}{c}\text { npc5 } \\
(\mathrm{At} 3 \mathrm{~g} 03540.1)\end{array}$ & $\begin{array}{l}\text { Фенотипические и физиологические } \\
\text { особенности не описаны [37] }\end{array}$ \\
\hline $\begin{array}{c}P G P 1 \\
(\text { At2g39290) }\end{array}$ & $\begin{array}{l}\text { Биосинтез ФИ; локализируется в пластидах и } \\
\text { митохондриях; кодирует фосфатсинтазу ФГ }\end{array}$ & $\begin{array}{c}\operatorname{pgp} 1 \\
(\mathrm{At} 2 \mathrm{~g} 39290.1)\end{array}$ & $\begin{array}{l}\text { Изменение структуры хлоропластов, но при } \\
\text { этом наблюдаются нормальные митохондрии; } \\
\text { бледно-зеленая окраска }[20,21]\end{array}$ \\
\hline
\end{tabular}

$d g d 1$ and $d g d 2$ carry null mutations, they have an alternative third way of DGDG synthesis, related to galactolipid galactosyltransferase (EC 2.4.1.184), localized in chloroplast membranes and synthesizing DGDG from MGDG in the absence of UDP-galactose. This alternative way is not related to the synthesis of galactolipids in plants in optimal nutrition conditions [17].

Synthases MGDG (type B) and DGDG, synthesized as a result of expression of genes MGD2, $M G D 3$ and $D G D 2$ in conditions of $\mathrm{P}_{\mathrm{i}}$ deficiency, are in the external membrane of chloroplasts $[13,17]$. All the predecessors, participating in MGDG synthesis, are transported from the endoplasmatic reticulum (ER) due to the absence of the active way of galactolipid synthesis in plants, notable for prokaryotes [18].

It is noteworthy that DGDG, synthesized in conditions of $\mathrm{P}_{\mathrm{i}}$ deficiency, is mainly localized in extraplastidic membranes; the enzymes, involved in the biosynthesis of this galactolipid, are located in plastid and other membranes. Therefore, the genes MGD2, $M G D 3$ and $D G D 2$ are likely to be involved in the biosynthesis of galactolipids of extraplastidic membranes, ER in particular, though at present there is no direct evidence confirming this fact.

The genes of $P G P$ family control the biosynthesis of phospholipids. The isoenzymes of phosphate-synthase PG (EC 2.7.8.5) in A. thaliana plants are encoded by two genes: $P G P 1$ and $P G P 2$ [20]. $P G P 1$ encodes the predecessor of the enzyme, localized in both plastids and mitochondria. The synthesis of microsome isoenzymes is controlled by $P G P 2[20,21]$. The significance of this gene for the biosynthesis of $\mathrm{PG}$ in plastids is demonstrated on modified plants of $A$. thaliana, where $P G P 1$ is partially or completely inactivated [21-23]. Contrary to plastids, PG deficiency in mitochondria is likely to be compensated by its delivery from ER where PG is synthesized with the participation of $P G P 2$ gene [21].

The $S Q D$ family is represented by two genes: $S Q D 1$ and SQD2. The biosynthesis in plant cells takes place only in plastids [24]. At the first stage the UDP-sulfoquinovose synthase (EC 3.13.1.1), controlled by $S Q D 1$, forms an activated carbohydrate derivative on the basis of sulphite and UDP-glucose [25-28]. At the next stage the synthase SQDG, encoded in plants by $S Q D 2$ and present in the internal membrane of chloroplasts, transfers sulfoquinovosyl-groups from UDP-sulfoquinovose to diacylglycerol (DAG) [27-29].

DAG, synthesized in plastids, is the substrate for the phosphate synthase of PG of photosynthetic membranes. At the same time, similarly to the synthases MGDG and DGDG, the synthase SQDG can use as a substrate DAG, synthesized not only in plastids, but also imported from ER [30]. This capability of the glycolipid synthases, together with the expression of specific genes, required for the DAG transformation due to phospholipid degradation into SQDG and DGDG, is the molecular foundation for the significant transformations of the membrane lipid composition at $\mathrm{P}_{\mathrm{i}}$ deficiency $[11,17,24,25,29,31-33]$. 
The genes, controlling the synthesis of phospholipases, are involved into the degradation of phospholipids, the synthesis of galactolipids, DAG and phosphatidic acid (PA) in plants. In particular, $P L D z$ genes encode the subfamily of PXPH-PLD proteins of phospholipase D (EC 3.1.4.4), which causes the phospholipid degradation and galactolipid formation in both photosynthetic and non-photosynthetic cells. The activation of $P L D z 1$ transcription results in the degradation of phospholipids in roots. PLDz2, expressed at $\mathrm{P}_{\mathrm{i}}$ deficiency in both roots and rosettes, initiates PC and PE hydrolysis with the formation of DAG [34-36].

The biosynthesis of non-specific phospholipase $\mathrm{C}$ (EC 3.1.4.3) is controlled by the transcription of NPC5 gene. In case of $\mathrm{P}_{\mathrm{i}}$ deficiency the phospholipase $\mathrm{C}$ causes the degradation of phospholipids and the synthesis of galactolipids synthesis in plant leaves [37].

The study on phosphatase and nuclease activity of genetically modified $A$. thaliana plants, cultivated at different $\mathrm{P}_{\mathrm{i}}$ concentrations, and subsequent identification of the genes present valuable information about the molecular mechanisms of regulation of $\mathrm{P}_{\mathrm{i}}$ homeostasis. The application of differential or subtractive hybridization of DNA-microchips revealed that the transcriptional level of several hundreds of genes is regulated by the change in $\mathrm{P}_{\mathrm{i}}$ concentration [38]. The functions of these genes are rather different which highlights the relevance of phosphorus for optimal functioning of cells. The results of various manipulations with genes allowed deepening the knowledge about their regulatory role in $\mathrm{P}_{\mathrm{i}}$ homeostasis.

An analysis of the level of gene transcription showed that at phosphorus deficiency 44 genes are involved in the biosynthesis of lipids of A. thaliana plants $(7 \%)$. Only two of them turned out to be suppressed. Approximately $50 \%$ genes, related to the lipid exchange, are expressed during two days after the beginning of $\mathrm{P}_{\mathrm{i}}$ deficiency. Primarily these are genes, encoding the enzymes, involved into the degradation of phospholipids and synthesis of galacto- and sulfolipids as well as into the DAG biosynthesis (Fig. 1) $[39,40]$. The transcriptional regulation only a few of them, participating in the biosynthesis of phospholipases $\mathrm{D}(P L D z 2)$ and $\mathrm{C}(N P C 5)$, is induced in the conditions of $\mathrm{P}_{\mathrm{i}}$ deficiency $[40,41]$.

The genes $M G D 2$ and $M G D 3$ are expressed 4-10 times faster, compared to $D G D 1$ and $D G D 2$, the induction of which, in its turn, is observed only after the action of medium- and long-term $\mathrm{P}_{\mathrm{i}}$ deficiency. Besides, the genes, encoding UDP-galactose i.e. UDP-glucose-4-epimerase and UDP-galactose-4-epimerase (UGE2 and UGE5), which transform UDP-glucose into UDP-galactose (the predecessors of galactolipids), are also expressed at medium- and long-term $\mathrm{P}_{\mathrm{i}}$ deficiency. For comparison: the genes, coding UDP-sulfoquinovose UDP-sulfoquinovosyl synthase and UDP-sulfoquinovosyl-DAG-sulfoquinovosyl transferase (SQD1 and $S Q D 2)$, are activated at both short- and long-term $P_{i}$ deficiency, which resulted in 4-fold increase in the SQDG level at long-term $P_{i}$ deficiency.

Such modulations in the regulation of transcription of the genes, participating in the biosynthesis of glycoand phospholipids, confirm the hypothesis of complex mechanism of substitution of membrane phospholipids with non-phosphorus-containing glycolipids in plants at $\mathrm{P}_{\mathrm{i}}$ deficiency [40].

The re-utilization of phosphorus of membrane phospholipids in conditions of $P_{i}$ deficiency. The substitutions of phospholipids with non-phosphorus-containing lipids in the membranes was first discovered in non-photosynthetic bacteria Pseudonomas diminuta [42] and then in photosynthetic organisms [43]. In genetically modified photosynthetic bacteria (Rhodobacter sp. and Synechococcus sp.), where non-phosphorus-containing SQDG is absent, its accumulation was found at $P_{i}$ deficiency $[43,44]$. The reversible interrelation between SQDG and $\mathrm{PG}$, depending on the level of $\mathrm{P}_{\mathrm{i}}$ provision, was also determined in A. thaliana plants [25]. The increase in SQDG content along with the PG destruction was established in Chlamydomonas reinharditti at $\mathrm{P}_{\mathrm{i}}$ deficiency [45]. These observations became a foundation of the hypothesis of substitution of $P G$ forSQDG in photosynthetic membranes [27, 29].

The investigations of mutant plants $A$. thaliana phol deficient in a protein, providing the input of $\mathrm{P}_{\mathrm{i}}$ into the xylem [9], testify that at $P_{i}$ deficiency the content 


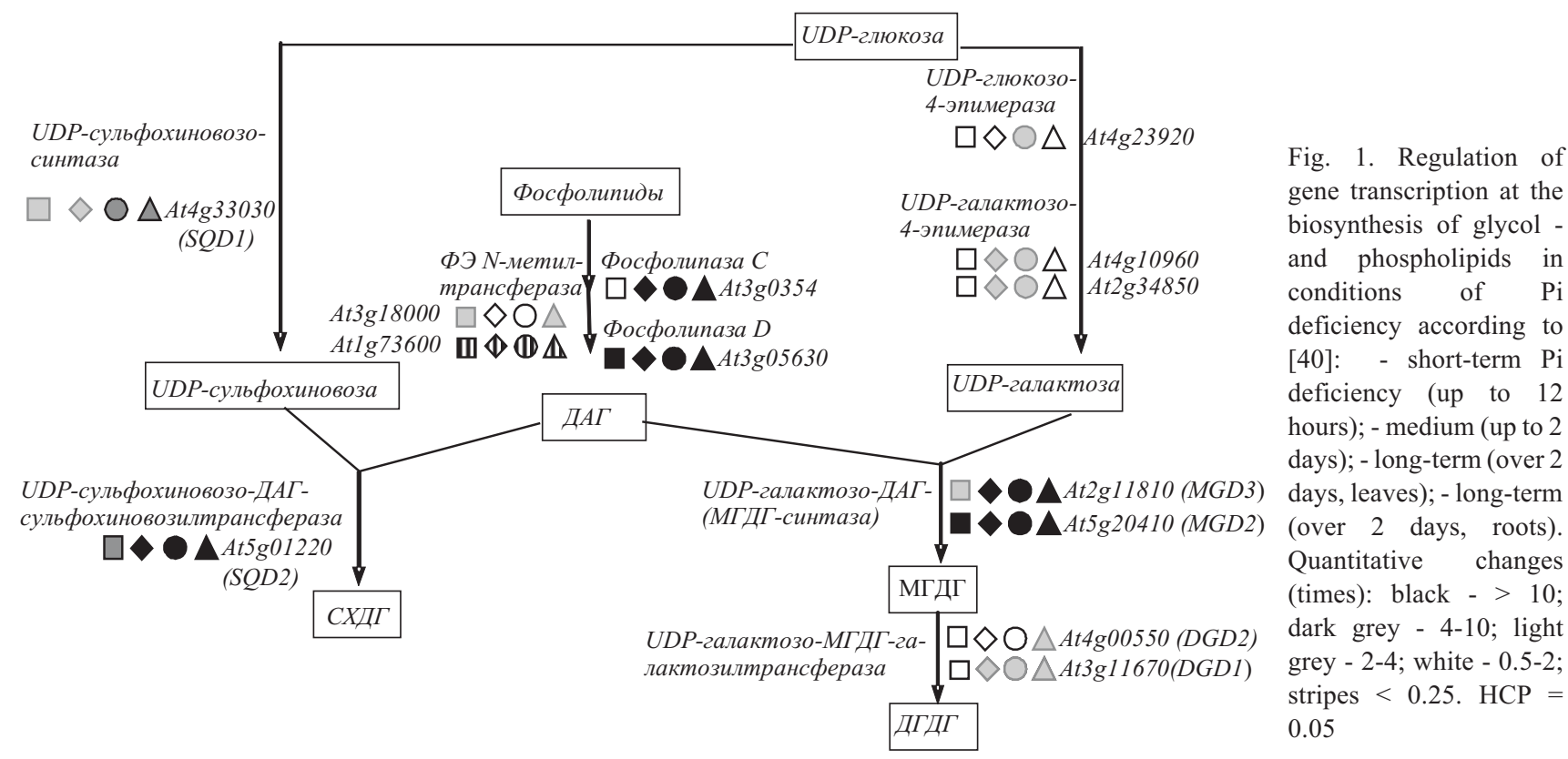

not only of SQDG, but also of DGDG increases. The accumulation of SQDG correlates with the increase in the protein content which proves an indirect participation of the latter in SQDG synthesis $[18,46]$.

An analysis of subcellular fractions of plastidic and extraplastidic membranes of $A$. thaliana revealed considerable increase in DGDG content in the membrane fraction of roots in conditions of $\mathrm{P}_{\mathrm{i}}$ deficiency in both wild and transformed plants $d g d l$ [18]. Along with an intense accumulation of DGDG in the fraction of non-photosynthetic membranes, less considerable increase in the relative content of this galactolipid was also observed in the membranes of chloroplasts of $\mathrm{P}_{\mathrm{i}}$-deficient non-modified and $d g d 1$-transformed plants.

For fad3-modified $A$. thaliana plants with inadequate synthesis of desaturase $\mathrm{C}_{18: 2}$ of the fatty acid (FA) associated with ER the accumulation of $\mathrm{C}_{18: 2}$ was found as well as a decrease in the level of $\mathrm{C}_{18: 3}$ of $\mathrm{FA}$ in the composition of DGDG of these plants. Since FAD3 mutation is primarily related to lipids, present in extraplastidic membranes, the changes in the ratio $\mathrm{C}_{18: 2}: \mathrm{C}_{18: 3}$ of FA DGDG of fad3-plants testify that DGDG is mainly localized in extraplastidic membranes [47].

Therefore, the obtained results confirmed the predominant accumulation of DGDG in plasmatic membranes of plants, cultivated at $\mathrm{P}_{\mathrm{i}}$ deficiency, which still does not rule out the possibility of this galactolipid accumulation in photosynthetic membranes as well.

The main lipids in extraplastidic membranes are galactolipid DGDG and phospholipid PC. They are neutral compounds, involved in the formation of the membrane bilayer. The analysis of FA in the composition of these lipids revealed their similarity. Therefore, it was assumed that $\mathrm{PC}$, synthesized at $\mathrm{P}_{\mathrm{i}}$ deficiency, in plasmatic membranes substitutes DGDG, like SQDG compensates PG in the membranes of chloroplasts $[25,46]$.

The comparative analysis of transformation of lipids of plasmatic membranes and chloroplast membranes demonstrated that short-term $\mathrm{P}_{\mathrm{i}}$ deficiency does not cause any significant modifications in the composition of neutral lipids of plasmatic membranes. At insignificant changes in PC there was no intense accumulation of DGDG in the membranes of roots of A. thaliana plants during two-day $\mathrm{P}_{\mathrm{i}}$ deficiency [40]. The data obtained show a lesser sensitivity of nonphotosynthetic membranes compared to chloroplast membranes at $\mathrm{P}_{\mathrm{i}}$ deficiency [48].

The re-utilization of phosphorus from phospholipids of membranes at $\mathrm{P}_{\mathrm{i}}$ deficiency is reversible. The studies on Avena sativa L. plants [demonstrated that at the renewed input of $\mathrm{P}_{\mathrm{i}}$ into plants 
a radioactively-labeled phosphorus is included first of all in the PC molecules and two days later over a half of phospholipids of plasmatic membranes in roots contained labeled phosphorus [49].

Investigation of functional activity of phospholipases, using the analysis of amino acid sequence of bacterial phospholipase $\mathrm{C}$, similar to that of A. thaliana, revealed six phospholipases Cs. Considerable activation of transcription of only one of them, non-specific phospholipase C4 (EC 3.1.4.3) $(N P C 4)$ [,] was observed at $\mathrm{P}_{\mathrm{i}}$ deficiency. Using molecular cloning and functional expression of NPC4, it was confirmed that this gene participates in encoding PC-hydrolysing phospholipase $\mathrm{C} 4$, the functional activity of which does not depend on the presence of $\mathrm{Ca}^{2+}$ ions [31]. The study of the activity of phospholipases $\mathrm{C}$ in A. sativa did not reveal their intense participation in the degradation of phospholipids of plasmatic membranes of $A$. sativa roots [49].

The presence of npc4 mutation in A. thaliana plants causes significant decrease in the PC-hydrolysing activity of phospholipase $\mathrm{C}$ due to $\mathrm{P}_{\mathrm{i}}$ deficiency. The data obtained allow an assumption about the participation of NPC4 in the delivery of both non-organic phosphate and DAG, formed due to the degradation of phospholipids in plasmatic membranes at $\mathrm{P}_{\mathrm{i}}$ deficiency [31].

Besides the activation of transcription of phospholipase $\mathrm{C} 4$, the increase in the activity of non-specific phospholipase C5 (NPC5) was determined in A. thaliana plants at $\mathrm{P}_{\mathrm{i}}$ deficiency. The analysis of the lipid fraction in mutant plants of $A$. thaliana demonstrated that the functional activity of NCP5 gene has significant] impact on the biosynthesis of DGDG in photosynthetic membranes at $\mathrm{P}_{\mathrm{i}}$ deficiency. The biosynthesis of DGDG in transformed plants npc5/phol decreased considerably compared to non-modified variants. The data obtained allowed the authors to make a conclusion about the dependence of approximately $50 \%$ of DGDG synthesis in photosynthetic membranes on the functionality of NPC5 gene at $\mathrm{P}_{\mathrm{i}}$ deficiency [37].

The determined functional activity of phospholipase D is in close correlation to the ratio of DGDG/PC at different levels of $\mathrm{P}_{\mathrm{i}}$ provision for plants.
The established correlation between the activity of phospholipase D and DGDG/PC ratio is in good agreement with the results, obtained on the model of substituting phospholipids with DGDG with the formation of PC in plasmatic membranes [49].

The studies on the intensity of phospholipid hydrolysis in roots and rosettes of $A$. thaliana determined their more intense degradation in plasmatic membranes of roots. Research of the activity of phospholipase $\mathrm{D}$ in A. thaliana plants on the example of genetically transformed plants pldz1, pldz2 and pldz1/pldz2 demonstrated that the disorder of functions of PLDz1 and PLDz2 leads to the reduction in PC degradation along with the diminution of DGDG accumulation in $\mathrm{P}_{\mathrm{i}}$-deficient plants. It was shown that PC hydrolysis with the participation of $P L D z$ at $\mathrm{P}_{\mathrm{i}}$ deficiency promotes the delivery of non-organic phosphorus for cellular metabolism and DAG - for the synthesis of galactolipids [35].

Thus, the complex approach using genetic, biochemical and physiological methods to study the transformation of glyco- and phospholipids revealed compensatory mechanisms of substitution of phospholipids with non-phosphorus-containing glycolipids in plastid and plasmatic membranes, which are manifested as a capability of plants to react to $P_{i}$ deficiency by selective accumulation of SQDG and DGDG (Fig.2). The modification of lipid components of membranes, directed towards the synthesis of non-phosphorus-containing glycolipids in response to $\mathrm{P}_{\mathrm{i}}$ deficiency, promotes the maintenance of developed systems of chloroplasts and plasmatic membranes of plants. Besides, phospholipids serve as a reserve pool of cellular phosphorus. The described re-utilization of phosphorus ions in the donor-acceptor system is one of the strategies allowing plants to adapt to the conditions of limited $\mathrm{P}_{\mathrm{i}}$.

\section{Н. Б. Светлова}

\section{Молекулярные составляющие метаболизма}

фосфо- и гликолипидов в мембранах растительных клеток в условиях дефицита фосфора

Учебно-научный центр «Институт биологии» Киевского национального университета имени Тараса Шевченко Ул. Владимирская, 64/13, Киев, Украина, 01601

Summary 


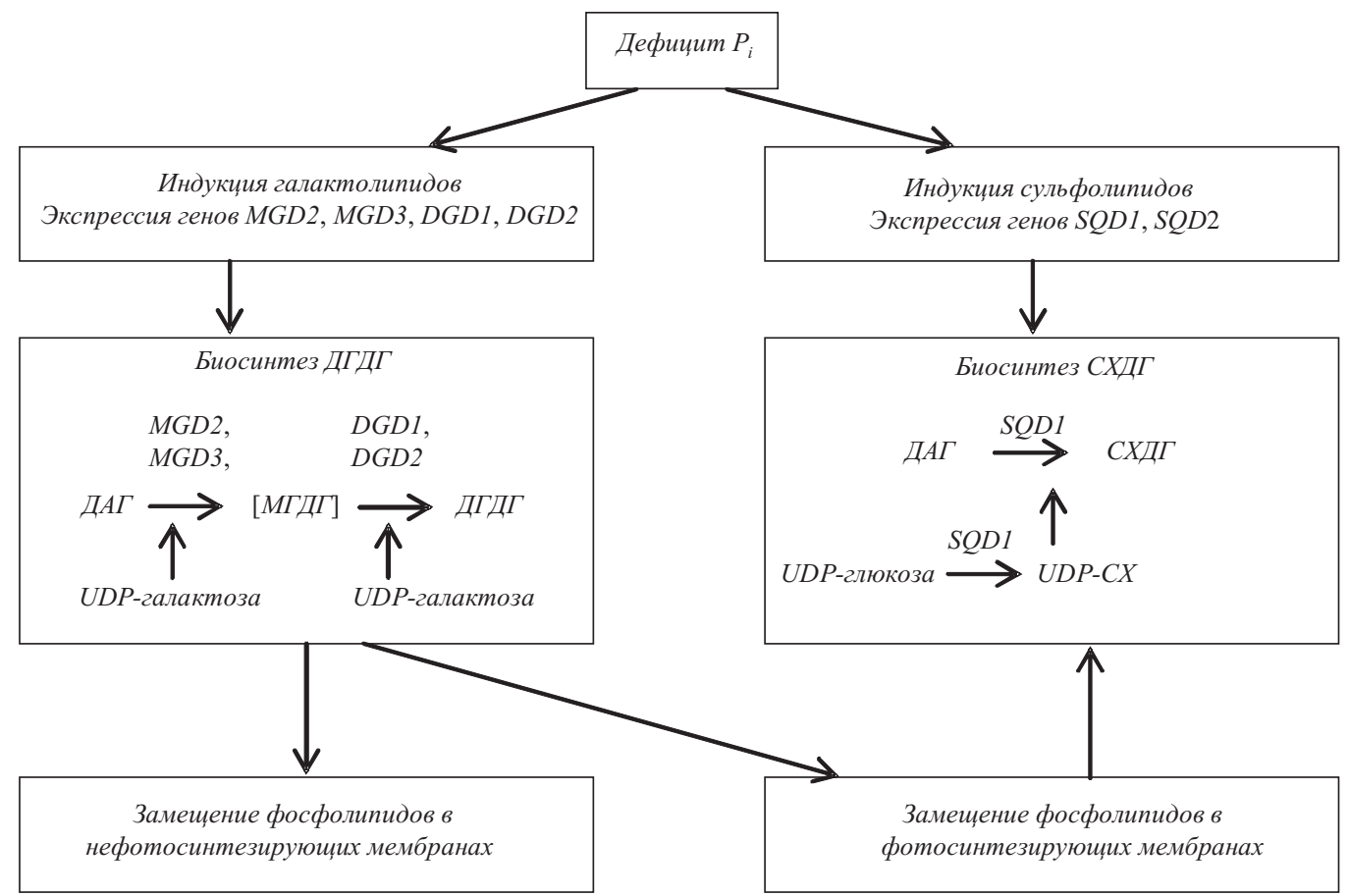

Fig. 2. Compensatory substitution of phospholipids with non-phosphorus-containing glycolipids in plastidic and extraplastidic membranes of plants at $\mathrm{P}_{\mathrm{i}}$ deficiency
Обзор посвящчен одной из составляющих молекулярной регулящии метаболизма фосфора в растительном организме - липидным компонентам мембранных структур. Изменение направленности метаболизма фосфо- и гликолипидов является показателем доступности фосфора растениям. Компенсатор- ные механизмьз замещения фосфолипидов нефосфоросодержащими гликолипидами в мембранах позволяют растениям адаптироваться к условиям ограничения поступления фосфатов $\left(P_{i}\right)$, а фосфолипиды служат резервным пулом клеточного фосфора при реутилизации ионов в донорно-акцепторной системе. Проанализированы механизмы транскрипционной регуляции генов, причастных $к$ синтезу фосфо- и гликолипидов в условиях дефиичта $P_{i}$.

Ключевые слова: дефицит фосфора, моногалактозилдиацилглицерол, дигалактозилдиацилглицерол, сульфохиновозилдиацилглицерол, фосфатидилглицерол, гень MGD, DGD, SQD, PLDz,

\section{NCP.Н. Б. Свєтлова}

Молекулярні складові метаболізму фосфо- і гліколіпідів мембран рослинних клітин за умов дефіциту фосфору

\section{Резюме}

Огляд присвячено одній із складових молекулярної регуляції метаболізму фосфору в рослинному організмі - ліпідним компонентам мембранних структур. Зміна спрямованості метаболізму фосфо- $i$ гліколіпідів є показником доступності фосфору рослинам. Компенсаторні механізми замімення фосфоліпідів нефосфоровмісними гліколіпідами у мембранах дозволяють рослинам адаптуватися до умов обмеження надходження фосфатів $\left(P_{i}\right)$, а фосфоліпіди слугують резервним пулом клітинного фосфору за реутилізації іонів у донорно-акиепторній системі. Проаналізовано механізми транскрипційної регулящії генів, залучених до синтезу фосфо- і гліколіпідів за умов дефіциту $P_{i}$.
Ключові слова: дефіцит фосфору, моногалактозилдіацилгліиерол, дигалактозилдіацилглічерол, сульфохіновозилдіацилгліцерол, фосфатидилгліцерол, гени $M G D, D G D, S Q D, P L D z, N C P$.

\section{REFERENCES}

1. Yuan H., Liu D. Signaling components involved in plant responses to phosphate starvation // J. Integr. Plant Biol.-2008.-50, N 7.-P. 849-859.

2. Raghothama K. G. Phosphate transport and signaling // Curr. Opin. Plant. Biol.-2000.-3, N 3.-P. 182-187.

3. Raghothama K. G. Phosphate acquisition // Annu. Rev. Plant. Physiol. Plant. Mol. Biol.-1999.-50.-P. 665-693.

4. Franco-Zorrilla J. M., Gonzalez E., Bustos R., Linhares F., Leyva A., Paz-Ares $J$. The transcriptional control of plant responses to phosphate limitation // J. Exp. Bot.-2004.-55, N 396.-P. 285293.

5. Poirier Y., Bucher M. Phosphate transport and homeostasis in Arabidopsis // The Arabidopsis book / Eds C. R. Somerville, E. M. Meyerowitz, M. D. Rockville.-New York: The Amer. Soc. of Plant Biologists Publ., 2002.-P. 1-35.

6. Joyard J., Marechal E., Block M. A., Douce R. Plant galactolipids and sulfolipid: structure, distribution and biosynthesis // Membranes: Specialized functions in plants / Eds M. Smallwood, P. Knox, D. J. Bowles.-Oxford: BIOS Sci. Publ., 1996.P. 179-194.

7. Browse J., Somerville C. Glycerolipid synthesis: biochemistry and regulation // Annu. Rev. Plant Physiol. Plant Mol. Biol.1991.-42.-P. 467-506.

8. Joyard J., Marechal E., Miege C., Block M. A., Dorne A. J., Douce $R$. Structure, distribution and biosynthesis of glycerolipids from higher plant chloroplasts // Lipids in photosynthesis: 
Structure, function and genetics / Eds P.-A. Siegenthaler, N. Murata.-Dordrecht: Kluwer Acad. Publ., 1998.- P. 21-52.

9. Poirier Y., Thoma S., Somerville C., Schiefelbein J. Mutant of Arabidopsis deficient in xylem loading of phosphate // Plant Physiol.-1991.-97, N 3.-P. 1087-1093.

10. Frentzen $M$. Phosphatidylglycerol and sulfoquinovosyldiacylglycerol: anionic membrane lipids and phosphate regulation // Curr. Opin. Plant Biol.-2004.-7, N 3.-P. 270-276.

11. Awai K., Marechal E., Block M. A., Brun D., Masuda T., Shimada H., Takamiya K., Ohta H., Joyard J. Two types of MGDG synthase genes, found widely in both $16: 3$ and 18:3 plants, differentially mediate galactolipid syntheses in photosynthetic and nonphotosynthetic tissues in Arabidopsis thaliana // Proc. Natl Acad. Sci. USA.-2001.-98, N 19.-P. 10960-10965.

12. Dormann P., Balbo I., Benning C. Arabidopsis galactolipid biosynthesis and lipid trafficking mediated by DGD1// Science.1999.-284, N 5423.-P. 2181-2184.

13. Kelly A. A., Dormann P. Green light for galactolipid trafficking // Curr. Opin. Plant Biol.-2004.-7, N 3.-P. 262-269.

14. Miuge C., Marechal E., Shimojima M., Awai K., Block M. A., Ohta H., Takamiya K., Douce R., Joyard J. Biochemical and topological properties of type A MGDG synthase, a spinach chloroplast envelope enzyme catalyzing the synthesis of both prokaryotic and eukaryotic MGDG // Eur. J. Biochem.-1999.-265, N 3.-P. 990-1001.

15. Kobayashi K., Nakamura Y., Ohta H. Type A and type B monogalactosyldiacylglycerol synthases are spatially and functionally separated in the plastids of higher plants // Plant Physiol. Biochem.-2009.-47, N 6.-P. 518-525.

16. Kobayashi K., Masuda T., Takamiva K., Ohta H. Membrane lipid alteration during phosphate starvation is regulated by phosphate signaling and auxin/cytokinin cross-talk // Plant J.-2006.47, N 2.-P. 238-248.

17. Kelly A. A., Froehlich J. E., Dormann P. Disruption of the two digalactosyldiacylglycerolsynthase genes $D G D 1$ and $D G D 2$ in Arabidopsis reveals the existence of an additional enzyme of galactolipid synthesis // Plant Cell.-2003.-15, N 11.-P. 2694 2706.

18. Hartel H., Dormann P., Benning C. DGD1-independent biosynthesis of extraplastidic galactolipids after phosphate deprivation in Arabidopsis // Proc. Natl Acad. Sci. USA.-2000.-97, N 19.P. 10649-10654

19. Kelly A. A., Dormann P. DGD2, an Arabidopsis gene encoding a UDP-galactose-dependent digalactosyldiacylglycerol synthase is expressed during growth under phosphate limiting conditions // J. Biol. Chem.-2002.-277, N 2.-P. 1166-1173.

20. Muller F., Frentzen $M$. Phosphatidylglycerophosphate synthases from Arabidopsis thaliana // FEBS Lett.-2001.-509, N 2.P. 298-302.

21. Babiychuk E., Muller F., Eubel H., Braun H. P., Frentzen M., Kushnir S. Arabidopsis phosphatidylglycerophosphate synthase 1 is essential for chloroplast differentiation, but is dispensable for mitochondrial function // Plant J.-2003.-33, N 5.-P. 899909.

22. Xu C., Hartel H., Wada H., Hagio M., Yu B., Eakin C., Benning $C$. The pgp 1 mutant locus of Arabidopsis encodes a phosphatidylglycerolphosphate synthase with impaired activity // Plant Physiol.-2002.-129, N 2.-P. 594-604.

23. Hagio M., Sakurai I., Sato S., Kato T., Tabata S., Wada H. Phosphatidylglycerol is essential for the development of thylakoid membranes in Arabidopsis thaliana // Plant Cell Physiol.2002.-43, N 12.-P. 1456-1464.

24. Dormann P., Benning C. Galactolipids rule in seed plants // Trends Plant Sci.-2002.-7, N 3.-P. 112-118.
25. Essigmann B., Guler S., Narang R. A., Linke D., Benning C. Phosphate availability affects the thylakoid lipid composition and the expression of $S Q D 1$, a gene required for sulfolipid biosynthesis in Aarabidopsis thaliana // Proc. Natl Acad. Sci. USA.1998.-95, N 4.-P. 1950-1955.

26. Sanda S., Leustek T., Theisen M. J., Garavito R. M., Benning C. Recombinant Arabidopsis SQD1 converts UDP-glucose and sulfite to the sulfolipid head group precursor UDP-sulfoquinovose in vitro // J. Biol. Chem.-2001.-276, N 6.-P. 3941-3946.

27. Taran N. Yu., Okanenko A. A., Kosyk O. I. Plant sulfolipid. II. Mutant study and phosphate deficiency // Biopolym. Cell.-2009.25, N 1.-P. 3-11.

28. Үи B., Хu C., Benning C. Arabidopsis disrupted in SQD2 encoding sulfolipid synthase is impaired in phosphate-limited growth // Proc. Natl Acad. Sci. USA.-2002.-99, N 8.-P. 5732-5737.

29. Benning $C$. Biosynthesis and function of the sulfolipid sulfoquinovosyl diacylglycerol // Annu. Rev. Plant Physiol. Plant Mol. Biol.-1998.-49.-P. 53-75.

30. Douce R., Joyard J. Biosynthesis of thylakoid membrane lipids // Advances in photosynthesis, oxygenic photosynthesis: The light reactions / Eds D. R. Ort, C. F. Yocum.-Dordrecht: Kluwer Acad. Publ., 1996.-Vol. 4.-P. 69-101.

31. Nakamura Y., Awai K., Masuda T., Yoshioka Y., Takamiya K., Ohta $H$. A novel phosphatidylcholine-hydrolyzing phospholipase $\mathrm{C}$ induced by phosphate starvation in Arabidopsis // J. Biol. Chem.-2005.-280, N 9.-P. 7469-7476.

32. Jouhet J., Marechal E., Bligny R., Joyard J., Block M. A. Transient increase of phosphatidylcholine in plant cells in response to phosphate deprivation // FEBS Lett.-2003.-544, N 1-3.P. 63-68.

33. Sato N., Hagio M., Wada H., Tsuzuki M. Environmental effects on acidic lipids of thylakoid membranes // Biochem. Soc. Trans.2000.-28, N 6.-P. 912-914.

34. Li M., Qin C., Welti R., Wang X. Double knockouts of phospholipases Df1 and Df2 in Arabidopsis affect root elongation during phosphate-limited growth but do not affect root hair patterning // Plant Physiol.-2006.-140, N 2.-P. 761-770.

35. Li M., Welti R., Wang X. Quantitative profiling of Arabidopsis polar glycerolipids in response to phosphorus starvation roles of phospholipases Df1 and Df2 in phosphatidylcholine hydrolysis and digalactosyldiacylglycerol accumulation in phosphorusstarved plants // Plant Physiol.-2006.-142, N 2.-P. 750-761.

36. Cruz-Ramirez A., Oropeza-Aburto A., Razo-Hernandez F., Ramirez-Chavez E., Herrera-Estrella L. Phospholipase DZ2 plays an important role in extraplastidic galactolipid biosynthesis and phosphate recycling in Arabidopsis roots // Proc. Natl Acad. Sci. USA.-2006.-103, N 17.-P. 6765-6770.

37. Gaude N., Nakamura Y., Scheible W. R., Ohta H., Dormann P. Phospholipase C5 (NPC5) is involved in galactolipid accumulation during phosphate limitation in leaves of Arabidopsis // Plant J.-2008.-56, N 1.-P. 28-39.

38. Lin W. Y., Lin S. I., Chiou T. J. Molecular regulators of phosphate homeostasis in plants // J. Exp. Bot.-2009.-60, N 5.-P. 14271438 .

39. Benning, $C$., Otha $H$. Three enzyme systems for galactoglycerolipid biosynthesis are coordinately regulated in plants // J. Biol. Chem.-2005.-280, N 4.-P. 2397-2400.

40. Misson J., Raghothama K. G., Jain A., Jouhet J., Block M. A., Bligny R., Ortet P., Creff A., Somerville S., Rolland N., Doumas P., Nacry P., Herrerra-Estrella L., Nussaume L., Thibaud M. C. A genome-wide transcriptional analysis using Arabidopsis thaliana affymetrix gene chips determined plant responses to phosphate deprivation // Proc. Natl Acad. Sci. USA.-2005.-102, N 33.-P. 11934-11939. 
41. Westphal S., Heins L., Soll J., Vothknecht U. C. Vipp1 deletion mutant of Synechocystis: a connection between bacterial phage shock and thylakoid biogenesis? // Proc. Natl Acad. Sci. USA.2001.-98, N 7.-P. 4243-4248.

42. Minnikin D. E., Abdolrahimzadeh H., Baddiley J. Replacement of acidic phospholipids by acidic glycolipids in Pseudomonas diminuta // Nature.-1974.-249, N 454.-P. 268-269.

43. Benning C., Beatty J. T., Prince R. C., Somerville C. R. The sulfolipid SQDG is not required for photosynthetic electron transport in Rhodobacter sphaeroides but enhances growth under phosphate limitation // Proc. Natl Acad. Sci. USA.-1993.-90, N 4.-P. 1561-1565.

44. Guler S., Seeliger A., Hartel H., Renger G., Benning C. A null mutant of Synechococcus sp. PCC7942 deficient in the sulfolipid SQDG // J. Biol. Chem.-1996.-271, N 13.-P. 7501-7507.

45. Sato N., Tsuzuki M., Matsuda Y., Ehara T., Osafune T., Kawaguchi A. Isolation and characterization of mutants affected in lipid metabolism of Chlamydomonas reinhardtii // Eur. J. Biochem.1995.-230, N 3.-P. 987-993.

46. Hartel H., Essigmann B, Lokstein H., Hoffmann-Benning S., Peters-Kottig M., Benning C. The phopholipid-deficient pho 1 mutant of Arabidopsis thalina is affected in the organization, but not in the light acclimation, of the thylakoid membrane // Biochim. Biophys. Acta.-1998.-1415, N 1.-P. 205-218.

47. Browse J., McConn M., James D. Jr., Miquel M. Mutants of Arabidopsis deficient in the synthesis of alpha-linolenate. Biochemical and genetic characterization of the endoplasmic reticulum li- noleoyl desaturase // J. Biol. Chem.-1993.-268, N 22.-P. 16345 16351.

48. Jouhet J., Marechal E., Baldan B., Bligny R., Joyard J., Block M. $A$. Phosphate deprivation induces transfer of DGDG galactolipid from chloroplast to mitochondria// J. Cell Biol.-2004.-167, N 5.-P. 863-874.

49. Tjellstrom H., Andersson M. X., Larsson K. E., Sandelius A. S. Membrane phospholipids as a phosphate reserve: the dynamic nature of phospholipid-to-digalactosyl diacylglycerol exchange in higher plants // Plant Cell Environ.-2008.-31, N 10.P. 1388-1398.

50. Kobayashi K., Awai K., Nakamura M., Nagatani A., Masuda T., Ohta $H$. Type B monogalactosyldiacylglycerol synthases are involved in phosphate starvation-induced lipid remodeling and are crucial for low-phosphate adaptation // Plant J.-2009.-57, N 2.-P. 322-331.

51. Holzl G., Witt S., Gaude N., Melzer M., Schottler M.A., Dormann $P$. The role of diglycosyl lipids in photosynthesis and membrane lipid homeostasis in Arabidopsis // Plant Physiol.-2009.-150, N 3.-P. 1147-1159.

52. Xu C., Moellering E. R., Fan J., Benning C. Mutation of a mitochondrial outer membrane protein affects chloroplast lipid biosynthesis // Plant J.-2008.-54, N 1.-P. 163-175.

Received 28.03.11 